\title{
Crop Coefficient and Evapotranspiration of Pomegranate (Punica granatum L.) for Western Part of Maharashtra, India
}

\author{
Deodas T Meshram ${ }^{1 *}$, Sunil D Gorantiwar ${ }^{2}$ and Saurabh S Wadne ${ }^{1}$ \\ ${ }^{1}$ ICAR-National Research Center on Pomegranate, India \\ ${ }^{2}$ Dr. A. S. Shinde College of Agriculture Engineering, India \\ *Corresponding Author: Deodas T Meshram, ICAR-National Research Center on Pomegranate, India.
}

Received: June 11, 2019; Published: June 25, 2019

DOI: 10.31080/ASAG.2019.03.0547

\begin{abstract}
The study was carried out to estimate reference crop evapotranspiration, develop crop coefficients, area factors and estimate crop evapotranspiration of pomegranate for western part of Maharshtra, India. The crop coefficient values were estimated for pomegranate plantation of $1^{\text {st }}$ year to maturity $\left(5^{\text {th }}\right.$ year $)$ on weekly basis from the concept of shaded area approach that is widely used for the deciduous crops. Pomegranate crop evapotranspiration was then determined on weekly basis for this region for $1^{\text {st }}, 2^{\text {nd }}, 3^{\text {rd }}, 4^{\text {th }}$ and $5^{\text {th }}$ years of pomegranate orchards for Ambia, Mrig and Hast Bahars. The values of water to be applied to pomegranate plantation spaced at $3 \times 4.5 \mathrm{~m}$ and irrigated by the drip irrigation system of $90 \%$ efficiency were estimated. These values would be useful for the appropriate irrigation water management of pomegranate orchards.
\end{abstract}

Keywords: Pomegranate; Reference Crop Evapotranspiration (ETr); Area Factor (AF); Pan Coefficient (PC); Crop Coefficient (Kc); Shaded Area (SA); Bahars

Pomegranate (Punica granatum L) cultivation today is a highly lucrative and remunerative agriculture business in India. The alluring monetary return per unit area from this crop has resulted in steady increase in area, production and export of pomegranate during last two decades. It is one of the oldest known edible fruits and is capable of growing in different agro - climatic conditions ranging from the tropical to temperate region. India occupies first position in pomegranate area and production globally [8]. Maharashtra State is a leading state for production of pomegranate and contributes more than $70 \%$ of its total production in India.

It is widely cultivated throughout India, Iran, China, Turkey, USA, Spain, Azerbaijan, Armenia, Afghanistan, Uzbekistan, the Middle East, Pakistan, Tunisia, Israel, dry regions of Southeast Asia, Peninsular Malaysia, the East Indies and tropical Africa. India is the world's leading countries in pomegranate production. The statistics on acreage and production of pomegranate are not available with Food and Agriculture organization at global level, however, estimated global cultivated area under pomegranate is around
3 lakh ha and production 3.0 million tones. In India, pomegranate is extensively grown in Maharashtra, Karnataka, Andhra Pradesh, Gujarat, and is picking up fast in, Himachal Pradesh, Rajasthan and Madhya Pradesh. Small areas are under cultivation in Tamil Nadu, Mizoram, Odissa, Nagaland, Lakshadweep, Jharkhand and Jammu and Kashmir. As per recent advance estimates for the year 2017, available at the National Horticulture Board of India website http://nhb.gov.in, total area under pomegranate in India is 1.27 lakh ha out of which $(90,000$ ha is in Maharashtra only [12]. Total production in India is 822.80 thousand MT (NHB 2017). Export of pomegranate has increased from 18.21 thousand MT (Rs. 710 million) in 2010-2011 to 31.33 thousand MT (Rs. 2985.0 million) in 2013-14 [5]. Thus, there is a need to enhance the productivity of pomegranate in India by appropriate scheduling and management of the resources including water.

Water is the most important natural resource for agricultural development and economic advancement of any country. But, it is one of the limiting factors for expansion of pomegranate produc- 
tion in arid and semi-arid regions of the world. Traditional irrigation methods (i.e. furrow, border and flood irrigation) deliver water to plants through gravity but usually results in substantial water losses and limited uniformity in water distribution. Modern irrigation technologies, i.e. surface, sub-surface drip and sprinkler irrigation results in higher water use efficiency as compared to traditional methods [7]. Water applied as per appropriate irrigation scheduling can influence pomegranate productivity and fruit quality [1].

Although, the crop is best suited for drought prone areas as it requires light texture soil and low rainfall of 180-550 mm [13] but the performance of the trees i.e. yield, fruit size, fruit quality, storability and long term productivity are highly dependent on adequate supply of water through irrgation. For maintaining productivity of the plants, generally one of the three bahars (flowering) is regulated, which depends upon market factors and availability of water resources [9]. The sudden change in soil moisture causes the moisture stress, which affects the fruit development adversely and leads to fruit cracking [3].

The water requirement is estimated from reference crop evapotranspiration (ETr) and crop coefficient (Kc). ETr depends on climatological parameters while Kc values are dependent upon age, stage, growth, canopy height, season, location and management strategies [1]. It has been demonstrated that the Kc is highly correlated canopy cover [4]. The development of simple method to estimate Kc values for pomegranate would be great benefit. Crop evapotranspiration is not easy to measure. Specific devices and accurate measurements of various physical parameters or the soil water balance in lysimeters are required to measure actual evapotranspiration. These methods are often expensive and demanding in terms of accuracy of measurements and can only be fully exploited by well trained research personal. Although, the methods are inappropriate for routine measurements, they remain important for the evaluation of ETr estimates obtained by indirect methods. However due to simplicity, indirect methods that use weather parameters are used for estimation of ETr. The crop evapotranspiration (ETc) is then estimated by multiplying ETr with crop coefficient (Kc). Hence, accurate estimation of ETr and Kc are of paramount importance for proper irrigation scheduling.

The main objective of this paper is to determine Kc values and estimate ETr for this region and present water to be applied for the pomegranate orchards during different weeks from their plan- tation for western part of Maharashtra. The paper presents the methodology used for determination of ETr, Kc, ETc and water to be applied and the bahar wise values.

\section{Materials and Methods}

As stated in the beginning of this paper it is important to know the values of ETr and Kc to estimate ETc. Kc values of most of the crops are not available locally and hence for irrigation water management of these crops, the Kc values reported by FAO are often used. So is the case with pomegranate too. Hence in this study it was decided to determine the Kc values locally and then use these values for estimation of ETc by knowing ETr. As the meteorological data can be readily available, ETr values in this study were estimated by the climatological approach rather than measuring it. This section describes the methods used for the determination of reference crop evapotranspiration (ETr), crop coefficient (Kc), area factor $(\mathrm{Fa})$, irrigation time (IT), shaded area (SA), water requirement (WR) values and water to be applied.

\section{Estimation of ETr}

It is proposed to use the Penman-Monteith method for the estimation of ETr as this method is widely used, recommended by FAO; and many researchers found this method close to the actual measurements of ETr compared to other methods. A consultation of experts and researchers was organized by FAO in May 1990, in collaboration with ICID and WMO, to review the FAO methodologies on crop water requirements and to advice on the revision and updates of procedures. The most common FA056-Penman Monteith method was used for the estimating reference crop evapotranspiration for the present study and is given by equation [1].

$\mathbf{E T}_{\mathbf{r}}=\frac{0.408 \Delta\left(\mathbf{R}_{\mathbf{n}}-\mathrm{G}\right)+\gamma\left(\frac{900}{\mathrm{~T}+273}\right) \mathbf{u}_{2\left(\mathrm{e}_{5}-\mathrm{e}_{\mathrm{a}}\right)}}{\Delta+\gamma\left(1+0.34 \mathbf{u}_{2}\right)}(1)$

Where, $\mathrm{ETr}=$ reference evapotranspiration $\left(\mathrm{mmday}^{-1}\right), \mathrm{G}=$ soil heat flux density $\left(\mathrm{MJ} / \mathrm{m}^{2} /\right.$ day), $\mathrm{Rn}=$ net radiation $\left(\mathrm{MJ} / \mathrm{m}^{2} /\right.$ day), $\mathrm{T}=$ mean daily air temperature $\left({ }^{0} \mathrm{C}\right), \gamma=$ psychometric constant $\left(\mathrm{kPa} /{ }^{\circ} \mathrm{C}\right), \Delta=$ slope of saturation vapour pressure function $(\mathrm{kPa} / 0 \mathrm{C})$, es = saturation vapour pressure at air temperature $\mathrm{T}$ $(\mathrm{kPa})$, ea $=$ actual vapour pressure at dew point temperature $(\mathrm{kPa})$, $\mathrm{u} 2=$ average daily wind speed at $2 \mathrm{~m}$ height $\left(\mathrm{msec}^{-1}\right)$.

\section{Determination of Kc values}

The Kc values vary with the crop growth stages and the age of the crop. The determination of Kc values needs the measurement 
of ETc and the estimation of ETr. ETc values need to be measured with help of lysimeters or soil moisture studies. As the pomegranate is a widely spaced fruit crops and stabilizes after 4-5 years, it is required to grow pomegranate for 4-5 years in large lysimeters. Such type of experimental set up is very expensive and takes lot of time to generate the information, though accurate. Hence in this study it was proposed to develop the Kc values with the help of shaded area approach that is adopted for many deciduous plantations.

For this purpose two commercial pomegranate orchards (Mrig Bahar) of $1^{\text {st }}$ to $5^{\text {th }}$ years each were selected and from each orchard 5 numbers of representative plants were randomly selected. The shaded area was measured at solar noon hour with the help of specially prepared plywood boards of $1.5 \times 1.5,2.5 \times 2.5,3.5 \times 3.5 \mathrm{~m}$ sizes with grid marking of size $20 \times 20 \mathrm{~cm}$. The total numbers grids occupied by shaded area were measured on a weekly basis for each selected plant. The crop coefficient was then calculated by equation [2], which is developed for deciduous fruit crops [6].

$\mathrm{Kc}=\mathbf{0 . 0 1 4 x}+\mathbf{0 . 0 8}(2)$

Where, $\mathrm{Kc}=$ Crop coefficient $\mathrm{x}=$ Percentage of shaded area, $(\%)$

By using the above stated equation, the week wise crop coefficient values were developed for different phenological stages i.e. new leaf initiation, crop development, crop maturity and crop harvesting for the orchards pruned in the month of May-June (Mrig Bahar) for ages from $1^{\text {st }}$ to $5^{\text {th }}$ year.

\section{Estimation of ETc}

The weekly values of ETr and Kc were used to obtain weekly values of ETc by equation (3) for Ambhe, Mrig and Hasta bahars for all the years.

$\mathrm{ETc}=\mathrm{ETr}^{*} \mathrm{Kc} \quad(3)$

Where, $\mathrm{ETc}=$ pomegranate evapotranspiration $\left(\mathrm{mmday}^{-1}\right), \mathrm{ETr}=$ reference crop evapotranspiration $\left(\mathrm{mmday}^{-1}\right), \mathrm{Kc}=$ crop coefficient of pomegranate.

\section{Water requirement (WR)}

The water requirement by the surface irrigation methods is equal to the crop evapotranspiration estimated by the equation (3). However water requirement by the drip irrigation method is less than the water requirement of the surface irrigation methods as in drip irrigation method unlike in surface irrigation method, it is possible to apply water to the effective root zone only. Hence water requirement in case of drip irrigation method is estimated by the equation (4).

$\mathrm{WR}=\mathrm{ETc} * \mathrm{Fa}$

Where, $\mathrm{WR}=$ water requirement $\left(\mathrm{mmday}^{-1}\right), \mathrm{Fa}=$ Area factor (fraction)

Irrigation Time (hrs)

$\mathbf{I T}=\frac{\mathbf{W R}}{\mathbf{D C}}(5)$

Where, IT -Irrigation time (hr); WR- Water requirement (Lday${ }^{1}$ tree $\left.^{-1}\right)$; DC-Dripper discharge capacity $\left(\mathrm{Lhr}^{-1}\right)$

\section{Area factor}

Area factor is the proportion of the effective root zone with respect to the total area. The area factor hence varies with the crop growth period and the age of the crop. In general it has been reported in the literature that for most of the deciduous crop, the effective root zone area below the soil surface is the area occupied by the canopy above the soil. In this study it was therefore considered that the canopy area is the effective root zone area. The area factor then is decided by knowing the canopy area and the area occupied by the tree. The canopy area is the shaded area at solar noon hour and was measured weekly for all the trees under experimentation i.e. the pomegranate tress of all the ages by using the procedure described above. Area factor was then computed by equation (6).

$\mathrm{Fa}=\mathrm{SA} / \mathrm{A}$

Where, $\mathrm{Fa}=$ Wetted area, $\mathrm{SA}=$ Shaded area measured at solar noon hour, $\left(\mathrm{m}^{2}\right), \mathrm{S}=$ Area occupied by one tree, $\left(\mathrm{m}^{2}\right)$

The wetted area was calculated on weekly basis for the pomegranate trees up to the age of $5^{\text {th }}$ years.

\section{Wetted Area (WA)}

Wetted area is the proportion of the effective wetted root zone with respect to the total area. Wetted Area can be calculated by equation (7).

$\mathrm{WA}=\mathrm{SA} / \mathrm{A} \quad(7)$

Where,

WA = Wetted area, $($ Fraction $) ; \mathrm{SA}=$ Shaded area, $\left(\mathrm{m}^{2}\right) ; \mathrm{A}=$ Area occupied by a tree, $\left(\mathrm{m}^{2}\right)$ 
The average wetted area can be calculated for the pomegranate trees of one to five years old (Table 4).

\section{Water to be applied}

The farmers need the information on water to be applied to each pomegranate tree. Water to be applied was estimated on weekly basis for the pomegranate trees up to the age of $5^{\text {th }}$ by using the equation (8).

$W A=W R * A /$ eff.

Where, WA = water to be applied to each tree $\left(\right.$ Lday $\left.^{-1}\right), A=$ area occupied by each tree $\left(\mathrm{m}^{2}\right)$, eff = efficiency of the drip irrigation system (fraction).

\section{Results and Discussion}

The average weekly reference crop evapotranspiration values estimated by Penman- Monteith method are presented in Figure 1. It is revealed from figure that, ETr is the highest in May (19-20 meteorological week-MW) and lowest in the month of December (49-52 MW). The weekly values of ETr are useful for obtaining the crop evapotranspiration of any crop for which the crop coefficient values are known. The mean annual value of reference crop evapotranspiration (ETr) as obtained by Penman-Monteith method is $1982.50 \mathrm{~mm}$ for Western Part of Maharashtra. The average weekly ETr values will be useful for daily or alternate day irrigation scheduling during Mirg, Hasta and Ambia bahars in pomegranate orchards.

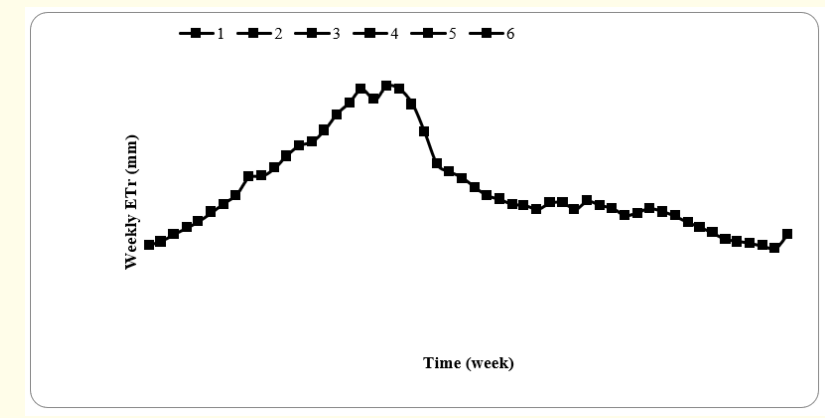

Figure 1: Average weekly ETr values for Western Part of Maharashtra.

The weekly values of shaded area and crop coefficient as determined by using the procedures explained in the methodology section are presented in Table 1 and Figure 2 for Ambhe, Mrig and Hasta bahars for the pomegranate trees of different ages. It is to be noted that the values were experimentally determined for the
Mrig bahar only and for other baharas, these values were appropriately adjusted. It is observed from the tables and Fig. that the shaded area increases from new leaf initiation to maturity period. During harvesting period shaded area decreases due to leaf drop, less application of irrigation water, removing of water sprout and harvesting of fruits. During the period from the new leaf initiation to crop development, the crop coefficient values increase during maturity period, the Kc values are around 1.1. At harvesting, the value of Kc decrease from 1.10 to 0.88 due to leaf drop, removing of water sprout, foliage crumbling and harvesting of fruits. The weekly crop coefficient values of pomegranate tree of different ages for different bahars shown in Figure 2 can be used for the estimation of pomegranate crop evapotranspiration provided that the values of reference crop evapotranspiration are known. The values of the weekly shaded area shown in this Table 1 for the pomegranate trees of different ages for different bahar treatments can be used to estimate the water requirement for the pomegranate plantation irrigated by the drip irrigation method, once the values of pomegranate crop evapotranspiration are estimated. The water to be applied to the pomegranate plantation irrigated by surface irrigation methods can be calculated by using the ETr values (Figure 1) and Kc values (Figure 2), if the efficiency of the surface irrigation method is known.

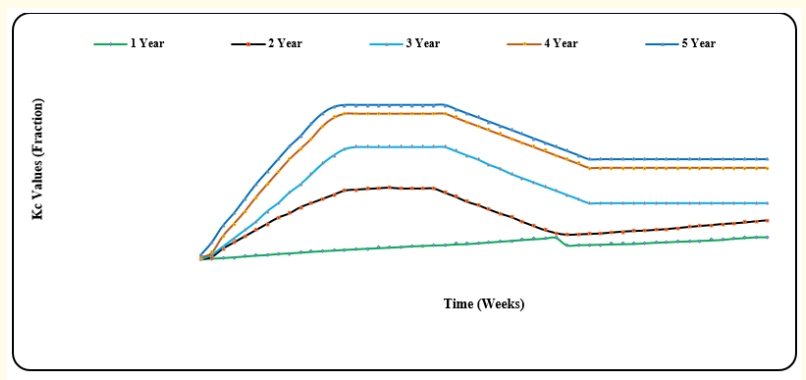

Figure 2: Average weekly crop coefficient (Kc) values of 1st to 5 th year pomegranate trees.

\begin{tabular}{|l|c|c|c|c|c|}
\hline \multirow{2}{*}{ Years } & \multicolumn{5}{|c|}{ Ages of tree } \\
\cline { 2 - 6 } & $\mathbf{1}^{\text {st }}$ & $\mathbf{2}^{\text {nd }}$ & $\mathbf{3}^{\text {th }}$ & $\mathbf{4}^{\text {th }}$ & $\mathbf{5}^{\text {th }}$ \\
\hline Shaded area $\left(\mathrm{m}^{2}\right)$ & 2.65 & 4.05 & 5.40 & 6.75 & 8.10 \\
\hline Area per plant $\left(\mathrm{m}^{2}\right)$ & 13.5 & 13.5 & 13.5 & 13.5 & 13.5 \\
\hline Wetted area (Fraction) & 0.20 & 0.30 & 0.40 & 0.50 & 0.60 \\
\hline
\end{tabular}

Table 1: Year wise wetted area of $1^{\text {st }}$ to $5^{\text {th }}$ old age pomegranate tree. 
According to different phenological stages of pomegranate, the period of new leaf initiation to $10 \%$ ground cover of tree is 25 days, the crop development period i.e. up to 60 to $80 \%$ ground cover of the tree is 65 days, the maturity to yellowness of leaves is 85 days and harvesting period when ripe fruits start falling on the ground or birds and squirrels start nibbling the fruits which are ripe is 65 days (Table 2). 240 numbers of days were required to complete all phenological events from new leaf initiation to harvesting. Bhagawa being the late maturing variety took more than 200 days from new leaf initiation to harvesting. Similar studies on Pomegranate, Apple and Peaches on duration across the phenological stages were reported by $[2,11]$.

\begin{tabular}{|l|l|c|c|}
\hline Sr. No. & Stages & Indicators & Days \\
\hline 1. & Initials & $\begin{array}{r}\text { Start of new leaves to } 10 \% \\
\text { ground cover }\end{array}$ & $0-21(21)$ \\
\hline 2. & $\begin{array}{l}\text { Crop Devel- } \\
\text { opment }\end{array}$ & $\begin{array}{c}10 \% \text { ground cover to } \\
\text { effective full cover, about } \\
60-70 \% \text { coverage for tree } \\
\text { crops }\end{array}$ & $22-99(77)$ \\
\hline 3. & Mid period & $\begin{array}{c}\text { Effective full cover to } \\
\text { maturity, indicated by yel- } \\
\text { lowing of leave, leaf drop } \\
\text { and browning of fruit. }\end{array}$ & $100-156(56)$ \\
\hline 4. & Harvesting & Maturity to harvest & $157-217(60)$ \\
\hline
\end{tabular}

Table 2: Phenological stages of pomegranate Bhagawa cv.

Pomegranate orchard needs to be provided with the water stress for the management purpose and abundant flowering. This period is 1 month or 2 months. However this period can be up to 2 months depending on the climate and soil types. After the stress period is over, it is necessary to bring the moisture content in the root zone to the field capacity. For this purpose, it is proposed to operate the drip irrigation system continuously for 24 to 48 hours. The values in the tables would be useful for irrigation scheduling of pomegranate by drip irrigation method from new leaf initiation to harvesting [10].

The water to be applied to the pomegranate plantation irrigated by drip irrigation method can be calculated by using the ETr values (Figure 1) and Kc values (Figure 2) and WA values (Table 1), if the efficiency of the drip irrigation method and the area covered by the pomegranate tree are known. Usually the pomegranate is spaced at $4.5 \times 3 \mathrm{~m}$ and the drip irrigation systems are designed for $90 \%$ efficiency. Hence, the values of water to be applied to pomegranate of different seasons for western part of Maharashtra state were estimated for the tree spacing of $4.5 \times 3.0 \mathrm{~m}$ and drip irrigation efficiency of $90 \%$. The values of water to be applied in liter/day/tree on weekly basis are presented in Tables 3, 4 and 5 for Mrig, Hasta and Ambia bahars.

\begin{tabular}{|c|c|c|c|c|c|c|c|c|c|c|c|}
\hline \multirow[t]{2}{*}{ MW } & \multicolumn{5}{|c|}{ Age of the plant } & \multirow[t]{2}{*}{ MW } & \multicolumn{5}{|c|}{ Age of the plant } \\
\hline & $1^{\text {st }}$ & $2^{\text {nd }}$ & $3^{\text {rd }}$ & $4^{\text {th }}$ & $5^{\text {th }}$ & & $1^{\text {st }}$ & $2^{\text {nd }}$ & $3^{\text {rd }}$ & $4^{\text {th }}$ & $5^{\text {th }}$ \\
\hline 23 & 3 & 5 & 0 & 8 & 1 & 39 & 2 & 9 & 16 & 25 & 31 \\
\hline 24 & 3 & 5 & 6 & 8 & 13 & 40 & 2 & 8 & 15 & 24 & 30 \\
\hline 25 & 3 & 5 & 7 & 11 & 16 & 41 & 2 & 8 & 16 & 24 & 30 \\
\hline 26 & 3 & 5 & 8 & 13 & 17 & 42 & 3 & 9 & 16 & 25 & 32 \\
\hline 27 & 3 & 6 & 0 & 15 & 2 & 43 & 3 & 9 & 18 & 27 & 34 \\
\hline 28 & 3 & 6 & 10 & 16 & 22 & 44 & 3 & 9 & 17 & 26 & 33 \\
\hline 29 & 2 & 7 & 11 & 18 & 23 & 45 & $J$ & 9 & 17 & 26 & 33 \\
\hline 30 & 2 & 7 & 10 & 17 & 23 & 46 & 3 & 8 & 16 & 25 & 32 \\
\hline 31 & 2 & 7 & 12 & 19 & 2 & 47 & 3 & 0 & 15 & 24 & 30 \\
\hline 32 & 2 & 8 & 13 & 21 & 27 & 48 & 3 & 7 & 15 & 23 & 29 \\
\hline 33 & 2 & 8 & 14 & 22 & 29 & 49 & 3 & 7 & 14 & 23 & 29 \\
\hline 34 & 2 & 8 & 14 & 23 & 29 & 50 & 3 & 6 & 13 & 21 & 27 \\
\hline 35 & 2 & 8 & 15 & 25 & 31 & 51 & 3 & 6 & 13 & 21 & 26 \\
\hline 36 & 2 & 9 & 16 & 25 & 32 & 52 & 3 & 6 & 12 & 20 & 25 \\
\hline 37 & 3 & 9 & 17 & 26 & 33 & 01 & 3 & 5 & 12 & 19 & 24 \\
\hline 38 & 2 & 8 & 16 & 24 & 31 & 02 & 3 & 6 & 12 & 20 & 26 \\
\hline
\end{tabular}

Table 3: Water to be applied (Lday ${ }^{-1}$ ) for $1^{\text {st }}$ to $5^{\text {th }}$ years old pomegranate tree during Mirg bahar.

\begin{tabular}{|c|c|c|c|c|c|c|c|c|c|c|c|}
\hline \multirow[t]{2}{*}{ MW } & \multicolumn{5}{|c|}{ Age of the plant } & \multirow[t]{2}{*}{ MW } & \multicolumn{5}{|c|}{ Age of the plant } \\
\hline & $\mathbf{1}^{\text {st }}$ & $2^{\text {nd }}$ & $3^{\text {rd }}$ & $4^{\text {th }}$ & $5^{\text {th }}$ & & $\mathbf{1}^{\text {st }}$ & $2^{\text {nd }}$ & $3^{\text {rd }}$ & $4^{\text {th }}$ & $5^{\text {th }}$ \\
\hline 36 & 2 & 3 & 4 & 5 & 6 & 52 & 2 & 8 & 16 & 24 & 30 \\
\hline 37 & 2 & 3 & 4 & 6 & 9 & 01 & 2 & 8 & 15 & 23 & 29 \\
\hline 38 & 2 & 4 & 5 & 8 & 11 & 02 & 2 & 8 & 16 & 24 & 30 \\
\hline 39 & 2 & 4 & 6 & 10 & 13 & 03 & 3 & 9 & 16 & 25 & 31 \\
\hline 40 & 2 & 4 & 7 & 11 & 15 & 04 & 3 & 10 & 18 & 28 & 35 \\
\hline 41 & 2 & 5 & 8 & 13 & 18 & 05 & 3 & 10 & 19 & 29 & 37 \\
\hline 42 & 2 & 6 & 9 & 15 & 20 & 06 & 3 & 10 & 20 & 31 & 39 \\
\hline 43 & 2 & 7 & 11 & 18 & 24 & 07 & 4 & 11 & 21 & 33 & 41 \\
\hline 44 & 2 & 7 & 12 & 19 & 25 & 08 & 4 & 11 & 23 & 35 & 44 \\
\hline 45 & 2 & 8 & 13 & 21 & 28 & 09 & 4 & 12 & 24 & 37 & 47 \\
\hline 46 & 2 & 8 & 14 & 22 & 29 & 10 & 5 & 12 & 24 & 39 & 49 \\
\hline 47 & 2 & 8 & 14 & 23 & 30 & 11 & 5 & 12 & 25 & 39 & 49 \\
\hline 48 & 2 & 8 & 15 & 24 & 31 & 12 & 6 & 12 & 25 & 41 & 52 \\
\hline 49 & 2 & 9 & 16 & 25 & 32 & 13 & 6 & 12 & 25 & 41 & 52 \\
\hline 50 & 2 & 8 & 16 & 24 & 30 & 14 & 6 & 12 & 25 & 41 & 52 \\
\hline 51 & 2 & 8 & 16 & 24 & 30 & 15 & 6 & 12 & 26 & 43 & 54 \\
\hline
\end{tabular}

Table 4: Water to be applied $\left(\right.$ Lday $\left.^{-1}\right)$ for $1^{\text {st }}$ to $5^{\text {th }}$ years old pomegranate tree during Hasta bahar. 


\begin{tabular}{|c|c|c|c|c|c|c|c|c|c|c|c|}
\hline \multirow{2}{*}{ MW } & \multicolumn{5}{|c|}{ Age of the plant } & \multirow{2}{*}{ MW } & \multicolumn{4}{|c|}{ Age of the plant } \\
\cline { 2 - 10 } & $\mathbf{1}^{\text {st }}$ & $\mathbf{2}^{\text {nd }}$ & $\mathbf{3}^{\text {rd }}$ & $\mathbf{4}^{\text {th }}$ & $\mathbf{5}^{\text {th }}$ & & $\mathbf{1}^{\text {st }}$ & $\mathbf{2}^{\text {nd }}$ & $\mathbf{3}^{\text {rd }}$ & $\mathbf{4}^{\text {th }}$ & $\mathbf{5}^{\text {th }}$ \\
\hline 1 & 2 & 3 & 3 & 5 & 6 & 17 & 5 & 19 & 35 & 54 & 68 \\
\hline 2 & 2 & 3 & 4 & 5 & 8 & 18 & 6 & 20 & 36 & 56 & 70 \\
\hline 3 & 2 & 4 & 5 & 8 & 11 & 19 & 6 & 19 & 36 & 56 & 70 \\
\hline 4 & 2 & 5 & 7 & 11 & 15 & 20 & 6 & 19 & 36 & 56 & 70 \\
\hline 5 & 2 & 6 & 8 & 13 & 18 & 21 & 6 & 19 & 35 & 54 & 67 \\
\hline 6 & 3 & 7 & 10 & 17 & 23 & 22 & 5 & 18 & 33 & 51 & 65 \\
\hline 7 & 3 & 8 & 12 & 20 & 27 & 23 & 4 & 14 & 27 & 42 & 53 \\
\hline 8 & 3 & 9 & 15 & 25 & 33 & 24 & 4 & 12 & 24 & 37 & 47 \\
\hline 9 & 4 & 11 & 18 & 30 & 39 & 25 & 4 & 11 & 22 & 33 & 42 \\
\hline 10 & 4 & 12 & 21 & 34 & 45 & 26 & 4 & 10 & 19 & 30 & 38 \\
\hline 11 & 4 & 13 & 24 & 38 & 50 & 27 & 4 & 9 & 18 & 29 & 37 \\
\hline 12 & 4 & 15 & 28 & 44 & 57 & 28 & 4 & 8 & 17 & 27 & 34 \\
\hline 13 & 5 & 16 & 30 & 48 & 60 & 29 & 3 & 7 & 15 & 25 & 32 \\
\hline 14 & 5 & 17 & 32 & 49 & 62 & 30 & 3 & 6 & 13 & 22 & 27 \\
\hline 15 & 5 & 18 & 33 & 51 & 64 & 31 & 3 & 6 & 13 & 21 & 27 \\
\hline 16 & 5 & 19 & 35 & 54 & 68 & 32 & 3 & 6 & 13 & 21 & 27 \\
\hline
\end{tabular}

\section{Bibliography}

1. Allen RG., et al. "Crop Evapotranspiration, Guideline for Computing Crop Water Requirements FAO Irrigation and Drainage Paper 56". FAO Rome, Italy (1998): 300.

2. Boland A., et al "Guide to best practices in water management: orchard crops, Murry-Darling Basin Commission, State of Victoria Department of Natural Resources and Environment, Melbourne". (2002).

3. Cheema GS., et al. "Fruits of India with special reference to Western India”. MacMilan and Company, Kolkata, India (1954).

4. de Medeiros GA., et al. "The influence of crop canopy on evapotranspiration and crop coefficient of beans (Phaseolus vulgaris L.)". Agricultural Water Management 49.3 (2001): 211-224.

5. http://agriexchange.apeda.gov.in

6. William LE and Ayars JE. "Grapevine water use and the crop coefficient are linear functions of the shaded area measured beneath the canopy". Agricultural and Forest Meteorology 132.3-4 (2005): 201-211.

Table 5: Water to be applied $\left(\mathrm{Lday}^{-1}\right)$ for $1^{\text {st }}$ to $5^{\text {th }}$ years pomegranate tree during Ambia bahar.

\section{Conclusion}

In summary, the Penman-Monteith method which is recommended by the FAO is the most accurate method for the estimation of reference crop evapotranspiration as evidenced from the literature. However, this method needs the large amount of data. The values of reference crop evapotranspiration that were estimated by the Penman-Monteith method and presented in this paper on weekly basis for the Western part of Maharashtra would be useful to estimate the crop evapotranspiration, if the values of crop coefficient are known. The crop coefficient values of pomegranate trees of $1^{\text {st }}$ to $5^{\text {th }}$ year maturity would be useful to estimate the crop evapotranspiration of pomegranate. The area factor values developed in this study would be useful to estimate the water requirement of pomegranate trees of different ages in combination with the crop coefficient values. The values of water to be applied to pomegranate (spaced at $3 \times 4.5 \mathrm{~m}$ ) irrigated by drip irrigation method of efficiency of $90 \%$ on weekly basis for western part of Maharashtra State would be useful for irrigation planning and optimum and efficient utilization of irrigation water for pomegranate orchards

7. Intrigliolo DS., et al. "Water relations of field grown pomegranate trees (Punica granatum L.) under different irrigation regimes". Agricultural Water Management 98.4 (2011): 691696.

8. Jadhav VT and Sharma J. "Pomegranate cultivation is very promising”. Indian Horticul 52 (2007): 30-31.

9. Meshram DT., et al. "Water Requirement of Pomegranate (Punica granatum L.) plants upto five year age". Journal Applied Horticulture 14.1 (2017): 47-51.

10. Meshram DT., et al. "Response of micro-irrigation systems on growth, yield and WUE of pomegranate (Punica granatum L.) in semi-arid regions of India". Scientia Horticultuare 246 (2019): 686-692.

11. Melgarejo P., et al. "Phenological stages of the pomegranate tree (Punica granatum L.)". Annals of Applied Biology 130.1 (1997): 135-140.

12. National Horticulture Board (2017).

13. Levin GM. "Pomegranate (1st Edn), Third Millennium Publishing, East Libra Drive Tempe”, AZ (2006): 120.

Volume 3 Issue 7 July 2019

(C) All rights are reserved by Deodas T Meshram., et al. 